\title{
Characterization of three Arracacia xanthorrhiza Bancroft genotypes using morphological and color parameters
}

\section{Caracterización de tres genotipos de Arracacia xanthorrhiza Bancroft mediante parámetros morfológicos y de color}
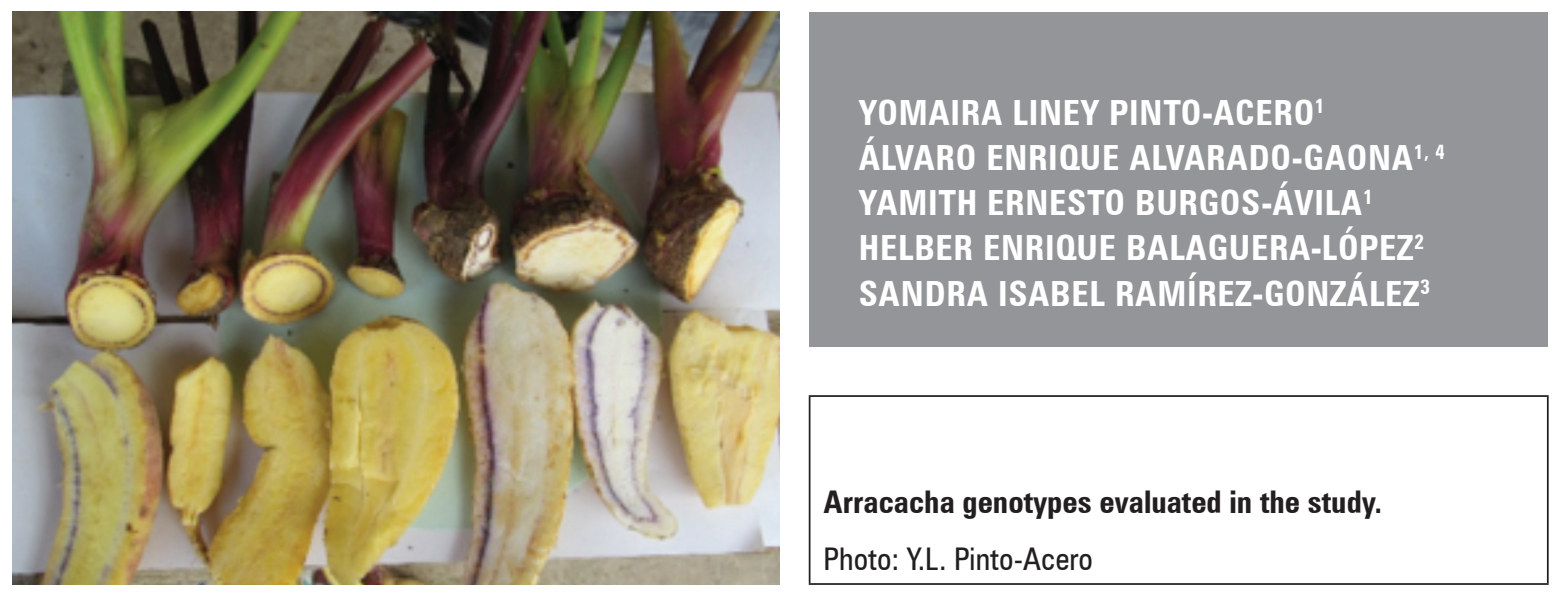

\begin{abstract}
In Colombia, the arrachacha is a crop with high economic and nutritional value. Despite its agricultural importance, few studies have focused on characterizing morphological parameters between genotypes. Some arracacha genotypes have been classified based on their qualitative traits such as coloration of the root, stem and leaf. Because of the variability of this characteristic, it is necessary to use the colorimetric system for greater precision. Color characterization was performed using the CIELab colorimetric system and morphological parameters (plant height, root diameter and number of fleshy roots) on three different genotypes of A. xanthorrhiza Bancroft (Yema de huevo, Paliverde and Yucatana) in the municipalities of Boyaca and Somondoco in the Department of Boyaca, Colombia. The results showed differences in the morphological characteristics plant height, root diameter and number of fleshy roots. The Yema de huevo genotype had a greater root number and diameter and a higher height, closely followed by the Paliverde genotype. This response depended on the environmental conditions of each municipality. The root and stem coloration had differences between the three genotypes, meaning these morphological characteristics can differentiate these genotypes. The Yema de huevo and Paliverde genotypes had the highest color index, a response that depended on the characteristics of each municipality. This research provides information on the physical characteristics of each genotype, which allows for easier visual identification.
\end{abstract}

\footnotetext{
Additional key words: arracacha; color index; leaf color; root color; stem color; Andean root.

Universidad Pedagógica y Tecnológica de Colombia (UPTC), Grupo de Investigación en Desarrollo y Producción Agraria Sostenible. Tunja (Colombia). ORCID Pinto-Acero, Y.L.: 0000-0001-5748-9853; ORCID Alvarado-Gaona, A.E.: 0000-0002-7024-5594; ORCID Burgos-Ávila, Y.E.: 0000-0002-8786-6311

2 Universidad El Bosque, Faculty of Sciences, Program of Biology, Grupo de Investigación de Biología de la Universidad El Bosque (GRIB). Bogota (Colombia). ORCID Balaguera-López, H.E.: 0000-0003-3133-0355

3 Universidad Autónoma de Chiapas, Centro Universidad Empresa. Tuxtla Gutierrez (México). ORCID Ramírez-González, S.I.: 0000-0002-1563-1521

4 Corresponding author. alvaro.alvarado@uptc.edu.co
} 


\section{RESUMEN}

En Colombia, la arrachacha es un cultivo con un alto valor económico y nutricional. A pesar de su importancia agrícola, pocos estudios se han enfocado en la caracterización de parámetros morfológicos entre genotipos. Algunos genotipos de la arracacha han sido clasificados con base en sus características cualitativas como color de la raíz, tallo y hojas. Debido a la variabilidad de esta característica se considera necesario el uso del sistema colorimétrico para mayor precisión. Se realizó la caracterización del color mediante el sistema colorimétrico CIELab y de algunos parámetros morfológicos en tres diferentes genotipos de A. xanthorrhiza Bancroft (Yema de Huevo, Paliverde y Yucatana), en los municipios de Boyaca y Somondoco del departamento de Boyacá, Colombia. Los resultados mostraron diferencias en características morfológicas tales como altura de la planta, diámetro de la raíz y número de raíces carnosas. El genotipo Yema de huevo presentó mayor número y diámetro de raíces, y mayor altura, seguido muy de cerca del genotipo Paliverde, esta respuesta dependió de las condiciones ambientales de cada municipio. La coloración de raíz y tallo registró diferencias de color entre los tres genotipos, siendo estas características morfológicas las que pueden servir para diferenciarlos. Los genotipos yema de huevo y paliverde fueron los que presentaron un mayor índice de color, respuesta que depende de las características de cada municipio. Esta investigación proporciona información relacionada con las características físicas propias de cada genotipo que puede permitir más fácilmente su identificación visual.

Palabras clave adicionales: arracacha; índice de color; color de la hoja; color del tallo; color de la raíz; raíces Andinas.

Received for publication: 02-08-2019 Accepted for publication: 29-11-2019
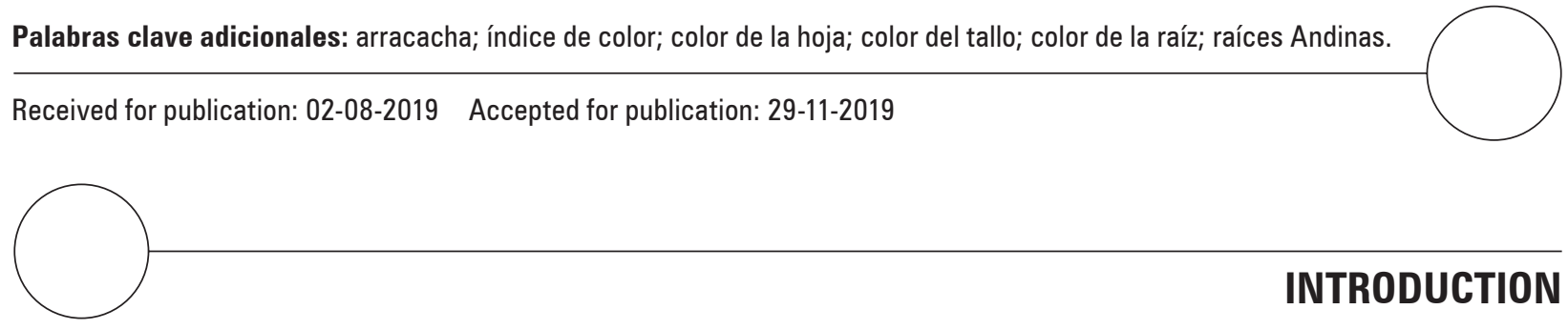

INTRODUCTION

Roots are one of the more important food products, after cereals in tropical regions (Chandrasekara and Kumar, 2016). In Colombia, arracacha (Arracacia xanthorrhiza Bancroft) is a product with high socioeconomic importance (Muñoz et al., 2015), like other crops in the zone (Gallo et al., 2018). In recent years, this crop has increased in the Boyaca Department, mainly in zones at altitudes between 2200 and 2800 $\mathrm{m}$ a.s.l. (Alvarado et al., 2016). In 2016, more than 6,500 ha of arracacha were planted in Colombia, with a total production of 70,000 $\mathrm{t}$, an average yield of 9.3 $\mathrm{t} \mathrm{ha} \mathrm{a}^{-1}$. In the case of Boyaca in 2016, production rates for arracacha, which represents a significant percentage of the cultivated land area (12.4\%), reached 13.47 $\mathrm{t} \mathrm{ha}^{-1}$ (Agronet, 2018). This root has a high nutritional value because of its high content of protein and macronutrients, such as calcium and phosphorous. Leidi et al. (2018) indicated that it has potential as functional foods. Moreover, this root is used in the pharmaceutical and cosmetic industries (Gutiérrez, 2011), and it can be used as an alternative source for starch extraction because of its attractive properties (Castanha et al., 2018; Londoño-Restrepo et al., 2018; Cruz-Tirado et al., 2019).

The arracacha is a minor ecosystem (Cleves-Leguízamo et al., 2017), one of the more ancient domesticated plants in the Americas; different types or varieties of arracacha genotypes have been characterized according to the descriptors developed by International Potato Center (CIP, Peru), with partial modifications done by CORPOICA's Plant Genetic Resources and Biotechnology program; these descriptors have exhibited a discriminatory power and have been easy to record at field and laboratory levels in Colombia (Lobo et al., 2002). Ignacio et al. (2017) found three different morphotypes of grown arracacha with 21 descriptors. Alvarado and Ochoa (2010) characterized some arracacha genotypes and found that one variety was white like radishes and turnips, another was yellow, and the last one was white with a violet ring around the insertion of the crown. This authors also reported that the root characterization was based mainly on the physical appearance, but there was not a morphological and genetic classification (Alvarado and Ochoa, 2010). Likewise, Muñoz et al. (2015) reported the preliminary characterization of six genetic materials in the Boyaca Department, which were named Huevo, Paliverde, Palirrusia, Palinegra, Sata, and Satamorada. This study was based on basic traits such as coloration of leaves, stem and roots, but the color was an estimate of the visual and qualitative form. This characterization leads to confusion among farmers when choosing a genotype. Because of the 
variability of this characteristic, it is necessary to use the colorimetric system for greater precision in physical characterizations.

On the other hand, environmental variations influence root quality, and differences between genotypes are not considered when these varieties are cultivated in different regions (Oliveira et al., 2005). Indeed, farmers tend to cultivate only two genotypes, not considering whether the light, soil and temperature are suitable for arracacha crops, which leads to a reduction in the number of genotypes and, in turn, an agro-biodiversity loss (Alvarado and Ochoa, 2010). In the last decade, this crop has seen growing demand, being cultivated in countries such as Australia, the United States and different Central American countries. Despite being long considered a crop with potential economic value, the plant is still almost exclusively produced by smallholder farmers, where $80 \%$ of farmers have farms under 3 ha (Alvarado et al., 2016). For these reasons, knowledge on arracacha biology, conservation, and the implementation of tools that allow scientists and farmers to recognize existing genetic materials or genotypes and their yield in different climate conditions is essential. This knowledge will allow farmers to reduce the loss of agrobriodiversity and increase arracacha crop production (Alvarado and Ochoa, 2010). Moreover, knowing the effects that different growing environments have on crops may provide information about changes related to pigments, nutrients, and others important aspects (Haynes et al., 2010).

The objective of this study was to carry out a characterization of color and morphologic parameters of three genotypes of Arracacia xanthorrhiza Bancroft (Yema de huevo, Paliverde and Yucatana) in Somondoco and Boyaca, Boyaca Department, Colombia.

\section{MATERIALS AND METHODS}

\section{Location}

The study was carried out in Somondoco and Boyaca, Boyaca Department (Colombia). Somondoco is localized to latitude $4^{\circ} 58^{\prime} 59^{\prime \prime} \mathrm{N}$, longitude $73^{\circ} 25^{\prime} 49^{\prime \prime} \mathrm{W}$, altitude: $1,670 \mathrm{~m}$ a.s.1., with solar radiation of 3.5-4 $\mathrm{kWh} \mathrm{m}^{-2}$, mean temperature of $19.9^{\circ} \mathrm{C}$ and precipitation of $1,340 \mathrm{~mm} \mathrm{y}^{-1}$. Boyaca (latitude $5^{\circ} 27^{\prime} 24^{\prime \prime} \mathrm{N}$, longitude $73^{\circ} 21^{\prime} 32^{\prime \prime} \mathrm{W}, 2,420 \mathrm{~m}$ a.s.l.) has a solar radiation of $4.5-5 \mathrm{kWh} \mathrm{m}^{-2}$, mean temperature of $15.2^{\circ} \mathrm{C}$ and precipitation of $992 \mathrm{~mm} \mathrm{y}^{1}$. The analyses were done in the Laboratory of Plant Physiology in the Faculty of Agricultural Sciences at the Universidad Pedagógica y Tecnológica de Colombia, Tunja.

\section{Morphological characterization}

Plant samples in the vegetative stage (which corresponds to 10 months after sowing) were collected. Five samples of plant material, from randomly selected batches $(n=30)$, were collected. Three genotypes: Yema de huevo, Paliverde and Yucatana of A. xanthorrhiza were characterized using morphology parameters. Yema de huevo and Paliverde are the most commercial genotypes, while Yucatana is a less commercial genotype and is mainly cultivated for selfconsumption (Alvarado and Ochoa, 2010; Alvarado et al., 2016).

Arracacha samples were washed in the laboratory and air dried before taking the measurements. The color was determined on the surface of the plant with the CIELab coordinates system L*, $\mathrm{a}^{*}$ and $\mathrm{b}^{*}$ (Mendoza et al., 2006; Balaguera-López et al. (2015) using a digital colorimeter, Minolta CR-300 (Minolta, Osaka, Japan). Each value was the average of three readings. $\mathrm{L}^{*}$ indicates luminosity and, $\mathrm{a}^{*}$ and $\mathrm{b}^{*}$ chrome. Negative $a^{*}$ values mean a green color, and positive values indicate a red color. For $b^{*}$, negative values mean a blue color, and positive values mean a yellow color. With the data, the color index was calculated using the formula $\mathrm{CI}=\left(1000 \times \mathrm{a}^{*}\right) /\left(\mathrm{L}^{*} \times \mathrm{b}^{*}\right)$. The secondary color index in the root (SCIR), primary color index in the root (PCIR), root pulp color index (RpCI), color index of upper side of leaf (CIUL), color index of back side of the leaf (CIBL), primary color index of the stem (PCIS) and secondary color index of the stem (SCIS) were measured. The predominant color in tissue was considered primary. All measurements were taken using the same parameter to measure surface color. The measurements were taken on fully expanded leaves, in the middle part of the stem and the roots.

The plant length was determined by measuring from ground level to the apex using a flexometer. The diameter was measured at the basal part of the fleshy root with a vernier caliper, and the number of fleshy roots was determined with direct counting.

\section{Statistical analysis}

The assumptions of the model were visually inspected, and the correct error distribution was chosen. A 
two-way ANOVA for medians in a completely random design using the WRS2 package (Mair and Wilcox, 2019) was performed in order to compare the effect of genotype, site, and their interaction on the different morphological variables (color index of the root, leaves and stem; length and number of roots and root diameter). The post hoc tests used to compare groups were percentile bootstrap (function mcp2a) and Tukey. The summary statistics were presented as median \pm IOR (interquartile range). Generalized linear models were used for analyzing the number of roots (Poisson); the mean \pm SD (standard deviation) were shown for this test. The software $\mathrm{R}$, version 3.5.1 (R Development Core Team 2018), was used for all Statistical analysis.

\section{RESULTS}

Significant differences in the secondary color index of the root between the genotypes and site were observed (Tab. 1). The Paliverde genotype had a higher index value (4.984) than 'Yema de huevo' and 'Yucatana'. Moreover, in Boyaca, higher coloration values (5.237) were observed than in Somondoco. An effect from the interaction on the secondary index color was not observed (Tab. 1).
There were differences between genotypes for the primary color index of the root, where 'Yema de huevo' (0.782) had higher values than 'Yucatana' $(-0.204)$. The site did not have any effect on the color, but the interaction was statistically significant. This means that the genotype differed in respect to each province. In Boyaca, 'Yema de huevo' had higher values (2.085; Tab. 1).

Statistical differences were found in the root pulp color index between the genotypes, where 'Paliverde' had higher color values (1.02) than 'Yema de huevo' $(-0.3975)$, but not Yucatana. The site and the interaction did not have any effect on the root pulp color index (Tab. 1).

In the color index of upper side of the leaf, differences between genotypes were not observed, but, between sites, there were differences (Tab. 1). Higher color index values were observed in Somondoco (-9.804) than in Boyaca (-11.515). Likewise, the interaction had an effect on the upper side of the leaves, with variation between the genotypes and the sites. In the Paliverde genotype in Boyaca, lower color values (-14.3) were observed in 'Yema de huevo' and 'Paliverde' than in Somondoco. The Yucatana genotype had lower values than 'Yema de huevo' and 'Paliverde' in Somondoco (Tab. 1).

Table 1. Means and $P$ values of the secondary color index of the root (SCIR), primary color index of the root (PCIR), root pulp color index $(\mathrm{RpCl})$, color index of upper side of leaf (CIUL), color index of back side of the leaf (CIBL), primary color index of the stem (PCIS) and secondary color index of the stem (SCIS), traits evaluated in the Yema de Huevo (YH), Paliverde (PV) and Yucatana (Y) genotypes in the municipalities of Boyaca (B) and Somondoco (S).

\begin{tabular}{|l|c|c|c|c|c|c|c|}
\hline Traits & SCIR & PCIR & RpCI & CIUL & CIBL & PCIS & SCIS \\
\hline Genotype & $<0.001$ & $<0.001$ & $<0.001$ & NS & NS & $<0.001$ & $<0.001$ \\
\hline YH & $3.901 \mathrm{~b}$ & $1.685 \mathrm{a}$ & $-0.3975 \mathrm{~b}$ & -9.937 & -8.851 & $-6.018 \mathrm{a}$ & $41.741 \mathrm{a}$ \\
\hline $\mathrm{PV}$ & $4.984 \mathrm{a}$ & $0.782 \mathrm{a}$ & $1.02 \mathrm{a}$ & -9.6695 & -8.1405 & $-5.2015 \mathrm{a}$ & $29.478 \mathrm{~b}$ \\
\hline $\mathrm{Y}$ & $3.247 \mathrm{~b}$ & $-0.204 \mathrm{~b}$ & $0.686 \mathrm{ab}$ & -11.4405 & -8.337 & $-13.8585 \mathrm{~b}$ & $19.112 \mathrm{~b}$ \\
\hline Site & $<0.05$ & $\mathrm{NS}$ & $\mathrm{NS}$ & $<0.001$ & $<0.001$ & $<0.001$ & $<0.001$ \\
\hline B & $5.237 \mathrm{a}$ & -0.037 & 0.626 & $-11.515 \mathrm{~b}$ & $-8.612 \mathrm{~b}$ & $-5.712 \mathrm{a}$ & $38.897 \mathrm{a}$ \\
\hline $\mathrm{S}$ & $3.912 \mathrm{~b}$ & 1.573 & 0.587 & $-9.804 \mathrm{a}$ & $-7.86 \mathrm{a}$ & $-6.324 \mathrm{~b}$ & $19.112 \mathrm{~b}$ \\
\hline Interaction & $\mathrm{NS}$ & $<0.001$ & $\mathrm{NS}$ & $<0.001$ & $<0.001$ & $<0.001$ & NS \\
\hline $\mathrm{YH} \times \mathrm{B}$ & 4.23 & $2.085 \mathrm{a}$ & -0.589 & $-11.501 \mathrm{bc}$ & $-9.535 \mathrm{~b}$ & $-5.712 \mathrm{ab}$ & 50.081 \\
\hline $\mathrm{PV} \times \mathrm{B}$ & 5.371 & $0.113 \mathrm{~cd}$ & 1.158 & $-14.3 \mathrm{c}$ & $-8.324 \mathrm{ab}$ & $-5.065 \mathrm{a}$ & 32.337 \\
\hline $\mathrm{Y} \times \mathrm{B}$ & 3.509 & $-0.312 \mathrm{c}$ & 0.648 & $-11.048 \mathrm{bc}$ & $-8.228 \mathrm{ab}$ & $-8.542 \mathrm{bc}$ & 23.856 \\
\hline $\mathrm{YH} \times \mathrm{S}$ & 3.89 & $1.285 \mathrm{ab}$ & -0.252 & $-7.162 \mathrm{a}$ & $-7.831 \mathrm{a}$ & $-6.324 \mathrm{ab}$ & 39.386 \\
\hline $\mathrm{PV} \times \mathrm{S}$ & 4.416 & $1.832 \mathrm{ab}$ & 0.869 & $-7.856 \mathrm{a}$ & $-7.454 \mathrm{a}$ & $-5.531 \mathrm{ab}$ & 19.112 \\
\hline $\mathrm{Y} \times \mathrm{S}$ & 2.985 & $0.11 \mathrm{abc}$ & 0.724 & $-12.377 \mathrm{bc}$ & $-8.446 \mathrm{ab}$ & $-20.062 \mathrm{c}$ & 12.692 \\
\hline
\end{tabular}

*Means with different letters indicate significant statistical differences for each factor and interaction, according to Tukey's test $(P<0.05)(n=5)$; NS $=$ not significant. 
The genotype did not have an effect on the color index of the back side of the leaf. However, a significant difference between sites was observed, where the most negative values (-8.612) were observed in Boyaca (Tab. 1). Moreover, the interaction had a significant effect on the color index of the back side of the leaf. 'Yema de huevo' showed negative values (-9.54) in Boyaca, as compared to Somondoco and the Paliverde genotype at this site.

The genotype, site and the interaction had a significant effect on the primary color index in the stem. The Yucatana genotype had low values (-13.86). Furthermore, Boyaca had less negative color values $(-5.712)$ than Somondoco. For the interaction, 'Yema de huevo' and 'Paliverde' in Boyaca and Somondoco had higher color values than 'Yema de huevo' in Somondoco (Tab. 1).

In the secondary color index of the stem, the genotype and site had an effect on the color variation, but the interaction did not. When the genotypes were compared, 'Yema de huevo' had higher color values (41.741). Between sites, the color index in Boyaca was higher with a value of 38.897 (Tab. 1).

The plant length of the genotypes showed differences between the Paliverde and Yucatana genotypes $(P=0.04)$, but not between the sites. Similarly, it was observed that the interaction between genotype and province for plant length was significant $(P=0.001)$.

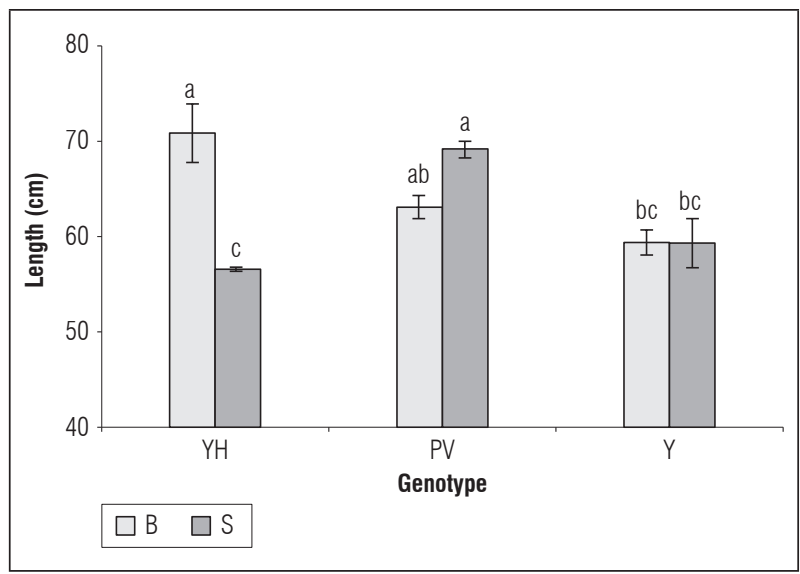

Figure 1. Effect of sites, Boyaca (B) and Somondoco (S), on plant length of three arracacha genotypes Yema de huevo (YH), Paliverde (PV), and Yucatana (Y). Medians with different letters indicate statistical differences, according to percentile bootstrap $(P<0.025)(n=5)$. The vertical bars indicate the interquartile range.
The genotype 'Yema de huevo' had a higher plant length in Boyaca than in Somondoco and 'Yucatana' in Boyaca. In addition, the Paliverde genotype had a longer plant length than 'Yema de huevo' in Somondoco and 'Yucatana' in Boyaca.

For the number of fleshy roots, there were significant differences between all genotypes $(P=0.001)$, where Yema de huevo had a higher number of roots than 'Paliverde' and 'Yucatana', and, in turn, 'Paliverde' had

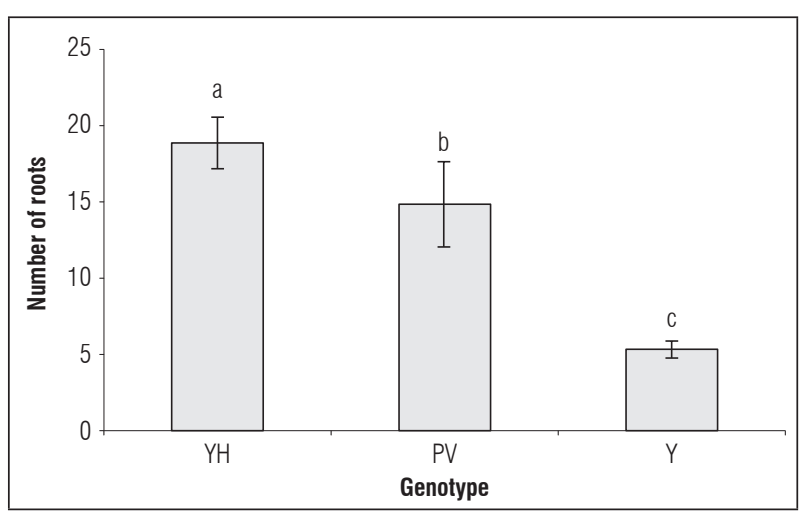

Figure 2. Differences in the number of roots between three arracacha genotypes Yema de huevo (YH), Paliverde (PV), and Yucatana (Y). Means with different letters indicate statistical differences according Tukey's test $(P<0.05)(n=5)$. The vertical bars indicate \pm standard error.

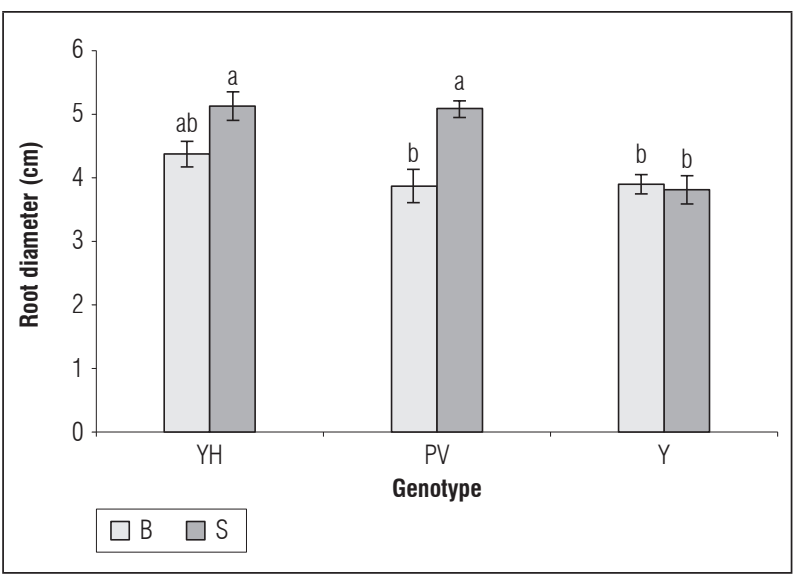

Figure 3. Effect of site, Boyaca (B) and Somondoco (S) on root diameter of three arracacha genotypes, Yema de huevo (YH), Paliverde (PV), and Yucatana (Y). Medians with different letters indicate statistical differences, according to percentile bootstrap $(P<0.025)(n=5)$. The vertical bars indicate the interquartile range. 
a higher number than 'Yucatana'. The site $(P=0.169)$ and the interaction between genotype and site did not have an effect on the root number (Fig. 2).

When the diameter of the root was compared, it was observed that the genotype $(P=0.001)$, site $(P=0.001)$ and interaction $(P=0.001)$ had a significant effect on the diameter. In Somondoco, the Yema de huevo and paliverde genotypes had a higher diameter (Fig. 3).

\section{DISCUSSION}

The change of coloration in the roots, leaves and stems was represented by the index color (Tab. 1). The CI may be correlated to pigment composition in vegetables tissues. Negative values represent green colors, while values higher than zero are related to yellow or red coloration (Mendoza et al., 2006; BalagueraLopez et al., 2017). In our case, it was observed that the secondary CI of the roots had positive values and that 'Paliverde' (dark brown) had a higher value than 'Yema de huevo' and 'Yucatana' (pale brownish), possibly because of anthocyanins present in the tissues (Azcon-Bieto and Talon, 2013).

Similarly, in Boyaca, the CI in all genotypes had higher values than in Somondoco, which indicates that location had an effect on this index, but that the interaction between them did not. Boyaca is located at a high altitude and presents major radiation, which stimulate the biosynthesis of anthocyanins as a protection mechanism against damage from excess radiation, which can affect the photosynthetic apparatus (Jimenez-Suancha et al., 2015). Similar differences have been observed in carrots, where changes in pigments are associated with temperature, light conditions, and humidity (García de Souza et al., 2012). In the primary $\mathrm{CI}$ of the root, it was observed that the interaction affected pigmentation in 'Paliverde' and 'Yema de huevo' (pale brown), as compared to 'Yucatana' (wheat color). For this parameter, differences were observed between the genotypes. In this case, 'Yema de huevo' (dark golden rod) and 'Paliverde' (pale brownish) showed positive values, and 'Yucatana' (olive) had negative values, which means that the root pigment content was affected by the genotype (Schmidt et al., 2018). These results agree with Muñoz et al. (2015), who reported that 'Yema de huevo' and 'Paliverde' genotypes had a yellow color in the root; this measurement was taken with the qualitative method. In addition, the differences between the genotypes was also due to the fact that some have a ring at the root, as seen in 'Paliverde'.

In the leaf color index (CIUL, CIBL, Tab. 1), it was observed that the interaction between genotype and site had significant effects, where fewer negative values were observed in Somondoco than in Boyaca. Moreover, the genotypes 'Yema de huevo' and 'Paliverde' had lower values in Boyaca (dark olive green) than in Somondoco (grey green), but the location did not affect the 'Yucatana' genotype. The pigment content in leaves and its accumulation depend on the amount that is produced, but the destruction of pigments is caused by factors such as wave length of radiation, temperature, and light intensity (Taiz and Zeiger, 2010; Macedo, 2012). For instance, light affects chlorophyll production in different types of plants and also in older and younger leaves (Manrique, 2003; Li et al., 2018). It is possible this could explain the variation in the coloration index between the genotypes in different regions, such as Boyaca, which has higher solar radiation, which reduces chlorophyll production, as compared to Somondoco. In the Paliverde and Yema de huevo genotypes, the visual color of the leaves was green (Alvarado and Ochoa, 2010; Muñoz et al., 2015).

Finally, it was observed that the interaction had an effect on the stem color index (Tab. 1). For the primary color index of the stem, the genotypes in Boyaca had higher color values than in Somondoco, 'Yema de huevo' and 'Paliverde' had olive colors, as compared to 'Yucatana', which showed a pale olive color. In the secondary color index of the stem, the genotypes and location only differed with respect to 'Yucatana', where 'Yema de huevo' had lower values than all genotypes and locations. As with the root and leaf $\mathrm{CI}$, the stem CI showed variation probably because of environmental variables such as temperature and solar variation. For instance, in Boyaca, an average temperature of $15.2^{\circ} \mathrm{C}$ and solar radiation of $4.5 \mathrm{~kW}$ $\mathrm{m}^{-2}$ were observed, as compared to Somondoco where the temperature is higher $\left(20^{\circ} \mathrm{C}\right)$ with a lower level of solar radiation $\left(3.5 \mathrm{~kW} \mathrm{~m}^{-2}\right)$ (Climate-Data, 2018).

It is important to highlight that a variety of environmental factors affect coloration and pigments in crops (Balaguera-López et al., 2017). Coloration changes in vegetables and fruits are correlated with pigment changes such as chlorophyll degradation (Quesada and Valpuesta, 2013; Paliyath et al., 2008). Knowledge on how growing environments affect individuals and coloration might provide evidence on pigment 
content, such as carotenoids in potatoes (Haynes et al., 2010). Similarly, different crop plant structures show diverse physiological, physical, chemical reactions, which in turn are affected by environmental conditions (Garcia de Souza et al., 2012). In the case of the arracacha, determining the optimal conditions for each genotype might increase yield, production and quality of crops.

According to the morphological variables analyzed in the genotypes Yema de huevo, Paliverde and Yucatan in Boyaca and Somondoco, variation in plant length was observed between the Paliverde genotypes with respect to 'Yema de huevo' and 'Yucatan'. The observed difference was most likely because 'Paliverde' grows better under the environmental conditions of Somondoco than the other genotypes, possibly because this municipality has a higher mean environmental temperature $\left(19.9^{\circ} \mathrm{C}\right)$, a situation that apparently favors cell division and elongation processes that generate a higher plant height. For 'Yema de huevo', the results show that this genotype grew better in Boyaca than in Somondoco (Fig. 1) because, in Boyaca, it might capture a higher proportion of light, which influences growth. Similar results have been observed in carrot crops where climate variations in different regions can affect adaptability, stability, production and yield of genotypes (Oliveira et al., 2005; García de Souza et al., 2012). The values obtained were higher than those reported by Lobo et al. (2002) in the southern Nariño arracacha collection, whose average plant height at harvest was $37.57 \mathrm{~cm}$.

For the number of roots, differences between genotypes were observed (Fig. 2), where 'Yema de huevo' had a higher number of roots. In this case, the location did not have an effect, meaning that the number of roots depended on the genotype, as reported by Oliveira et al. (2005). This parameter is important because it is a yield component, so, 'Yema de huevo' may be a more productive genotype.

On the other hand, Lobo et al. (2002) reported similar values for root width (root diameter) to those found in this study. It was observed that the diameter of the roots was affected by genotype, location, and the interaction between these variables. The Yema de huevo and Paliverde genotypes in Somondoco had a higher diameter than in Boyaca, The Somondoco site has a higher temperature and precipitation average than Boyaca (Climate-Data, 2018). Therefore, it is likely that the environmental conditions in Somondoco, such as temperature and humidity, can generate more root growth, mainly as a result of increased metabolic activity, according to Azcón-Bieto and Talón (2013). It has been shown that higher temperatures increase photosynthesis and the transport rate of photo assimilates from leaves to sink organs (Taiz and Zeiger, 2010). It is important to note that 'Yema de huevo' is a well-adapted genotype, with better growth at both sites (Figs. 1, 2, 3) because this genotype appears to have high rates of photosynthesis and a high percentage of photassimilates stored in sink organ, as Vega et al. (2012) observed in carrots.

The highest values of root diameter and number of roots have been reported for cassava at lower altitudes (Noerwijati and Budiono, 2015), probably caused by the higher temperature at lower altitudes. Similarly, it is probable that a higher production and number of roots are related to a higher photosynthetic rate, as found by Jaimez et al. (2008) in arracacha crops, where plants cultivated at a lower altitude $(1,580$ $\mathrm{m})$ had a higher photosynthetic rate and yield than plants cultivated at higher altitudes $(1,930)$. Effect of the zone was also found by Vergel et al. (2016).

\section{CONCLUSION}

The results show variation in all morphological traits of the genotypes Yema de huevo, Paliverde and Yucatana with respect to location. Color differences from the CIElab coordinate system were found between the genotypes, except in the leaves, indicating that the root and stem coloration can differentiate the genotypes. However, this response depended on the characteristics of each municipality, where 'Yema de huevo' and 'Paliverde' presented a higher color index than the Yucatan genotype. Also, the genotypes Yema de huevo and Paliverde had better performance in both sites (Boyaca and Somondoco), with a longer plant length, higher number of roots, and larger diameter. This information may allow for a more correct visual identification of each arracacha genotype

Conflict of interests: The manuscript was prepared and reviewed with the participation of the authors, who declare that there exists no conflict of interest that puts at risk the validity of the presented results.

\section{BIBLIOGRAPHIC REFERENCES}

Agronet. 2018. Área, producción y rendimiento nacional de arracacha en 2016. In: Ministerio de Agricultura y Desarrollo Rural of Colombia, http://www.agronet. 
gov.co/estadistica/Paginas/default.aspx; consulted: October, 2018.

Alvarado, A., A. Muñoz, and O. Adame. 2016. Una aproximación al desarrollo rural, caso el cultivo de arracacha, en el departamento de Boyaca. Ing. Reg. 16(2), 57-63. Doi: 10.25054/22161325.1299

Alvarado, A. and L. Ochoa. 2010. Tecnologías locales de producción de arracacha (Arracacia xanthorrhiza Bancroft) en el municipio de Boyaca, departamento de Boyaca. Rev. U.D.C.A Act. \& Div. Cient. 13(1), 125-133.

Azcón-Bieto, J. and M. Talón (eds.). 2013. Fundamentos de fisiología vegetal. $2^{\text {nd }}$ ed. Interamericana McGraw-Hi1l, Madrid.

Balaguera-López, H.E., M. Espinal-Ruiz, L. Zacarías, and A.O. Herrera. 2017. Effect of ethylene and 1-methylcyclopropene on the postharvest behavior of cape gooseberry fruits (Physalis peruviana L.). Food Sci. Technol. Int. 23, 86-96. Doi: 10.1177/1082013216658581

Balaguera-López, H.E., C.A. Martínez, and A. Herrera. 2015. Refrigeration affects the postharvest behavior of 1-methylcyclopropenetreated cape gooseberry (Physalis peruviana L.) fruits with the calyx. Agron. Colomb. 33(3), 356-364. Doi: 10.15446/agron.colomb. v33n3.51896

Castanha, N., J. Villar, M. da Matta Junior, C. Prudente dos Anjos, and P. Augusto. 2018. Structure and properties of starches from Arracacha (Arracacia xanthorrhiza) roots. Int. J. Biol. Macromol. 117, 1029-1038. Doi: 10.1016/j.ijbiomac.2018.06.015

Chandrasekara, A. and T. Kumar. 2016. Roots and tuber crops as functional foods: a review on phytochemical constituents and their potential health benefits. Int. J. Food Sci. 2016, 3631647. Doi: 10.1155/2016/3631647

Cleves-Leguízamo, J.A., J. Toro-Calderón, L.F. Martínez-Bernal, and T. Loeón-Sicard. 2017. La Estructura Agroecológica Principal (EAP): novedosa herramienta para planeación del uso de la tierra en agroecosistemas. Rev. Colomb. Cienc. Hortic. 11(2), 441-449. Doi: 10.17584/rcch.2017v11i2.7350

Climate-Data. 2018. Data sources. In: https://es.climate-data.org/info/sources/, consulted: September, 2018.

Cruz-Tirado, J.P., R. Vejarano, D. Tapia-Bácido, G. Barraza-Jáuregui, and R. Siche. 2019. Biodegradable foam tray based on starches isolated from different Peruvian species. Int. J. Biol. Macromol. 125, 800-807. Doi: 10.1016/j.ijbiomac.2018.12.111

Gallo, Y., L.F. Toro, H. Jaramillo, P.A. Gutiérrez, and M. Marín. 2018. Identificación y caracterización molecular del genoma completo de tres virus en cultivos de lulo (Solanum quitoense) de Antioquia (Colombia). Rev. Colomb. Cienc. Hortic. 12(2), 281-292. Doi: 10.17584/ rcch.2018v12i2.7692
García de Souza, M., B. Rocha, A. Gallo, G. Galván, A. Borges, and F. Záccari. 2012. Comportamiento agronómico y calidad de poblaciones locales de zanahoria en el sur del Uruguay. Agrociencia 16(1), 86-96.

Gutiérrez, A. 2011. Nueva aparcería en la producción de arracacha (Arracacia xanthorrhiza) en Cajamarca (Colombia). Cuad. Desarro. Rural 8(67), 205-228.

Haynes, K.G., B.A. Clevidence, D. Rao, B.T. Vinyard, and J.M. White. 2010. Genotype x environment interactions for potato tuber carotenoid content. J. Amer. Soc. Hort. Sc. 135, 250-258. Doi: 10.21273/ JASHS.135.3.250

Ignacio, S., F. Camarena, J. Baudoin, and R. Blas. 2017. Ethno-Botany and in-situ conservation of the genetic diversity of arracacha (Arracacia xanthorrhiza Bancroft), yacon (Smallanthus sonchifolious H.Robinson), and wild relatives. Peruv. J. Agron. 1 (1), 21-31. Doi: 10.21704/pja.v1i1.1064

Jaimez, R.E., N. Santos, B. Añez, J. Vásquez, and W. Espinoza. 2008. Photosynthesis of field-grown Arracacha (Arracacia xanthorrhiza Bancroft) cultivars in relation to root-yield. Sci. Hortic. 118(2), 100-105. Doi: 10.1016/j.scienta.2008.05.027

Jiménez-Suancha, S.C., O.H. Alvarado, and H.E. Balaguera-López. 2015. Fluorescencia como indicador de estrés en Helianthus annuus L. Una revisión. Rev. Colomb. Cienc. Hortíc. 9(1), 149-160. Doi: 10.17584/ rcch.2015v9i1.3753

Leidi, E., A. Monteros, G. Mercado, J.P. Rodríguez, A. Ramos, G. Alandia, M. Sørensen, and S.E. Jacobsen. 2018. Andean roots and tubers crops as sources of functional foods. J. Funct. Foods 51, 86-93. Doi: 10.1016/j. jff.2018.10.007

Li, Y., N. He, J. Hou, L. Xu, C. Liu, J. Zhang, Q. Wang, X. Zhang, and X. Wu. 2018. Factors influencing leaf chlorophyll content in natural forests at the biome scale. Front. Ecol. Evol. 6, 1-10. Doi: 10.3389/ fevo.2018.00064

Lobo, M., C.A. Rosso, and C.I. Medina. 2002. Morphologic characterization and agronomic evaluation of a Colombian collection of arracacha (Arracacia xanthorrhiza Bancroft). Plant Genet. Resour. Newsl. 132, 22-29.

Londoño-Restrepo, S.M., N. Rincón-Londoño, M. Contreras-Padilla, B.M. Millan-Malo, and M.E. Rodriguez-Garcia. 2018. Morphological, structural, thermal, compositional, vibrational, and pasting characterization of white, yellow, and purple Arracacha Legolike starches and flours (Arracacia xanthorrhiza). Int. J. Biol. Macromol. 113, 1188-1197, Doi: 10.1016/j. ijbiomac.2018.03.021

Macedo, A.F. 2012. Abiotic stress responses in plants: metabolism to productivity. pp. 41-62. In: Ahmad, P. and M. Prasad (eds). Abiotic stress responses in plants. Springer, New York. Doi: 10.1007/978-1-4614-0634-1_3 
Mair, P. and R. Wilcox. 2019. Robust statistical methods in R using the WRS2 package. Behav. Res. Methods. Doi: 10.3758/s13428-019-01246-w

Manrique, R.E. 2003. Los pigmentos fotosintéticos, algo más que la captación de luz para la fotosíntesis. Ecosistemas 12(1). URL: https://www.revistaecosistemas.net/index.php/ecosistemas/article/view/250

Mendoza, F., P. Dejmek, and J.M. Aguilera. 2006. Calibrated color measurements of agricultural foods using image analysis. Postharvest Biol. Technol. 41, 285-295. Doi: 10.1016/j.postharvbio.2006.04.004

Muñoz, A., A. Alvarado, and P. Almanza-Merchán. 2015. Caracterización preliminar del cultivo de arracacha Arracacia xanthorrhiza Bancroft en el departamento de Boyaca. Rev. Cienc. Agr. 32(1), 3-11. Doi: 10.1016/j. postharvbio.2006.04.004

Noerwijati, K. and R. Budiono. 2015. Yield and yield components evaluation of cassava (Manihot esculenta Crantz) clones in different altitudes. Energ. Proc. 65, 155-161. Doi: 10.1016/j.egypro.2015.01.050

Oliveira, C.D., L.T. Braz, and D.A. Banzatto. 2005. Adaptabilidade e estabilidade fenotípica de genótipos de cenoura. Hort. Bras. 23(3), 743-748. Doi: 10.1590/ S0102-05362005000300011
Paliyath, G., P.D. Murr, K. Handa, and S. Lurie (eds.). 2008. Postharvest biology and technology of fruits, vegetables, and flowers. Wiley-Blackwell Publishing, Ames, IA.

Quesada, M.A. and V. Valpuesta. 2013. Senescencia y abscisión. pp. 559-576. In: Azcón-Bieto, J. and M. Talón (eds.). Fundamentos de fisiología vegetal. $2^{\text {nd }}$ ed. Interamericana McGraw-Hill, Madrid.

Schmidt, L., S. Sorg, S. Tittman, J. Max, and J. Zinkernage. 2018. Do extended cultivation periods and reduced nitrogen supply increase root yield and anthocyanin content of purple carrots? Horticulturae 4(7), 3-13. Doi: 10.3390/horticulturae4020007

Taiz, L. and E. Zeiger. 2010. Plant physiology. $5^{\text {th }}$ ed. Sinauer Associates, Sunderland, MA.

Vega, R., C. Mendéz, and W. Rodríguez. 2012. Análisis del crecimiento de cinco híbridos de zanahoria (Daucus carota L.) mediante la metodología del análisis funcional. Agron. Costarric. 36(2), 29-46.

Vergel, M., J. Martínez, and S. Zafra. 2016. Cultivo de cebolla y su comportamiento en la Provincia de Ocaña. Rev. Colomb. Cienc. Hortíc. 10(2), 333-344. Doi: 10.17584/rcch.2016v10i2.5070 